ARTIGOS / ARTICLES

\title{
PCR Amplification and Sequence Analyses of Reverse Transcriptase- like Genes in Crinipellis perniciosa Isolates
}

\author{
Jorge F. Pereira ${ }^{1}$, Mariana D.C. Ignacchiti ${ }^{1}$, Elza F. Araújoํ, Sérgio H. Brommonschenkel², \\ Júlio C.M. Cascardo ${ }^{3}$, Gonçalo A. G. Pereira ${ }^{4}$ \& Marisa V. Queiroz ${ }^{1}$
}

${ }^{1}$ Departamento de Microbiologia, BIOAGRO; ${ }^{2}$ Departamento de Fitopatologia, BIOAGRO, Universidade Federal de Viçosa, CEP 36571-000, Viçosa MG, Brazil; ${ }^{3}$ Departamento de Ciências Biológicas, Universidade Estadual de Santa Cruz, CEP 45650-000, Ilhéus BA, Brazil; ${ }^{4}$ Departamento de Genética e Evolução, Universidade Estadual de Campinas, CEP 13083-970, Campinas SP, Brazil; e-mail: mvqueiro@ufv.br

Author for correspondence: Marisa V. Queiroz

PEREIRA, J.F., IGNACCHITI, M.D.C., ARAÚJO, E.F., BROMMONSCHENKEL, S.H., CASCARDO, J.C.M., PEREIRA, G.A.G. \& QUEIROZ, M.V. PCR amplification and sequence analyses of reverse transcriptase-like genes in Crinipellis perniciosa isolates. Fitopatologia Brasileira 32:373-380. 2007.

\begin{abstract}
Reverse transcriptase (RT) sequence analysis is an important technique used to detect the presence of transposable elements in a genome. Putative RT sequences were analyzed in the genome of the pathogenic fungus $C$. perniciosa, the causal agent of witches' broom disease of cocoa. A 394 bp fragment was amplified from genomic DNA of different isolates of $C$. perniciosa belonging to C-, L-, and S-biotypes and collected from various geographical areas. The cleavage of PCR products with restriction enzymes and the sequencing of various RT fragments indicated the presence of several sequences showing transition events (G:C to A:T). Southern blot analysis revealed high copy numbers of RT signals, forming different patterns among C-, S-, and L-biotype isolates. Sequence comparisons of the predicted RT peptide indicate a close relationship with the RT protein from the gypsy family of LTR-retrotransposons. The possible role of these retrotransposons in generating genetic variability in the homothallic C. perniciosa is discussed.
\end{abstract}

Additional keywords: genetic variability, transposable elements, witches' broom, Theobroma cacao.

\begin{abstract}
RESUMO
Amplificação por PCR e análises de seqüências de genes do tipo transcriptase reversa em isolados de Crinipellis perniciosa

A análise de sequências de transcriptase reversa (RT) é uma etapa importante para descobrir a presença de elementos transponíveis e investigar o seu papel na geração de variabilidade genética em $C$. perniciosa. Seqüências putativas de TR foram analisadas no genoma do fitopatógeno C. perniciosa, o agente causal da doença vassoura-de-bruxa no cacau. Um fragmento de 394 pb foi amplificado a partir do DNA genômico de diferentes isolados de C. perniciosa, pertencentes aos biótipos $\mathrm{C}, \mathrm{L}$ e S e a distintas áreas geográficas. A clivagem dos produtos de PCR com diferentes enzimas de restrição e sequenciamento de vários fragmentos de TR indicou a presença de diferentes seqüências mostrando eventos de transição G: C para A:T. A análise por hibridização revelou alto número de sinais sugerindo a presença de cópias de TR com diferentes perfis entre os isolados dos biótipos C, S e L. As comparações de seqüências dos peptídeos preditos indicam uma relação próxima com a proteína TR de retrotransposons-LTR da família gypsy.
\end{abstract}

Palavras-chave adicionais: variabilidade genética, transposons, vassoura de bruxa, Theobroma cacao.

\section{INTRODUCTION}

Reverse transcriptase (RT) is a fundamental enzyme for the transposition of Class I transposable elements. There are two major groups of Class I retrotransposons, one that contains long terminal repeats (LTR retrotransposons - Gypsy/Ty3-like and Copia/Tyl-like) and the other that lacks LTRs and possesses a polyadenylate sequence at its 3'

Present Address of the first author: Embrapa Trigo, Cx. Postal 451, CEP 99001-970, Passo Fundo RS, Brazil. termini (non-LTR retrotransposons - LINE-like and SINElike). The first retroelement reported for filamentous fungi was the Tad element of Neurospora crassa Shear \& B.O. Dodge isolated via an insertion into glutamate dehydrogenase gene (Kinsey \& Helber, 1989). Over the last 15 years, more than 30 retroelements were reported in different species of filamentous fungi, mainly from poorly characterized species and, in most cases, without a described sexual cycle (for a review, see Daboussi and Capy, 2003).

These retroelements present an extraordinary potential to promote modifications through their insertion and excision mechanism, as well as for the recombination 
between dispersed elements in the genome (see reviews in Daboussi \& Capy, 2003; Kazazian Jr., 2004). These modifications are essential for the generation of genetic variability within a species. In phytopathogenic fungi, the studies of these elements can increase the knowledge of the genetic structure of natural populations (Daboussi, 1997).

Although transposable elements are widespread in the eukaryotic genome, many of them are inactive. One mechanism that is responsible for the irreversible inactivation of duplicated sequences, such as transposable elements, was found in $N$. crassa. This mechanism is known as RIP (repeat-induced point mutation) and efficiently detects duplications of gene-sized DNA segments, linked or unlinked, and generates $\mathrm{G}: \mathrm{C}$ to A:T mutations in both copies of the duplicated DNA (Selker \& Garret, 1988; Cambaberi et al., 1989). RIP-like processes have been previously identified in other fungi, such as Aspergillus fumigatus Fresen., Magnaporthe grisea (T.T. Hebert) M.E. Barr, Podospora anserina (Rabenh.) Niessl, Leptosphaeria maculans (Desm.) Ces. \& De Not., Microbotryum violaceum (Pers.) G. Deml \& Oberw. and Ophiostoma Syd. (Neuvéglise et al., 1996; Nakayashiki et al., 1999; Hamann et al., 2000; Hood et al., 2005; Attard et al., 2005; Bouvet et al., 2007), and constitute important protection mechanisms against the deleterious effects of transposition (Kinsey et al., 1994; Galagan \& Selker, 2004).

Crinipellis perniciosa is a basidiomycete (Agaricales, Tricholomataceae), causal agent of witches' broom in cocoa tree (Theobroma cacao). According to pathogenicity data, this species is subdivided into three biotypes: (1) C-biotype, infecting Theobroma and Herrania species (Sterculiaceae) (Evans, 1978; Bastos et al., 1988); (2) S-biotype, infecting a number of species of the family Solanaceae (Bastos \& Evans, 1985); and (3) L-biotype, a saprophyte that colonizes a variety of substrates (Evans, 1978; Hedger et al., 1987). Witches' broom is considered one of the most severe cocoa diseases and has accounted, in the last two decades, for the drop in Brazilian cocoa production, turning the country from being one of the world's main cocoa exporters to a net importer. Because of the great impact of this disease on the main cocoa producing regions of Brazil, a consortium comprising a number of Brazilian institutions was created to sequence the genome of C. perniciosa (www.lge.ibi.unicamp. $\mathrm{br} /$ vassoura). Search analysis by sequence comparison in the Crinipellis Genome database revealed the presence of sequences showing homology to RT sequences from other organisms.

In this paper, the presence and distribution of putative reverse transcriptase sequences in isolates of $C$. perniciosa from different biotypes and geographical areas were analyzed. PCR and Southern analyses led to the identification of different putative RT sequences in C-biotype isolates and the presence of polymorphic fragments among $\mathrm{C}, \mathrm{S}$, and Lbiotypes, and between different C-biotype isolates. Possible involvement of the sequences related to transposable elements and the genetic variability of $C$. perniciosa are discussed.

\section{MATERIALS AND METHODS}

\section{Fungal strains}

The C-, S- and L-biotype isolates of Crinipellis perniciosa examined in this study are listed in Table 1 . These isolates were grown in PDA (Potate Dextrose Agar) and incubated at $27^{\circ} \mathrm{C}$.

\section{Primer construction}

Based on a sequence showing similarity to a reverse transcriptase (RT) found in the C.perniciosa genome database (GenBank accession n ${ }^{\circ} \mathrm{AY} 676620$ ), a pair of primers was used to amplify a $394 \mathrm{bp}$ fragment. The primers for RT amplification were RT1 (5'-TGCCAAAGAAACAGGGACTT-3') and RT2 (5'-GAATTTGCGAGACCGAAAAA-3').

\section{DNA extraction, PCR amplification, and restriction analysis}

Total DNA of the isolates was extracted as described

TABLE 1 - Isolates of Crinpellis perniciosa analyzed in this work

\begin{tabular}{llclll}
\hline \hline $\begin{array}{l}\text { Isolate } \\
\text { number }\end{array}$ & $\begin{array}{c}\text { Collection } \\
\text { Identification }\end{array}$ & Biotype & \multicolumn{1}{c}{ Locality } & \multicolumn{1}{c}{ Host } & $\begin{array}{c}\text { Responsible } \\
\text { Institution* }\end{array}$ \\
\hline 1 & Biotipo L & L & Pichilinge - Equador & Arrabidaea verrucosa & UW \\
2 & SABA & C & Santo Amaro BA & $\begin{array}{l}\text { Theobroma cacao } \\
\text { Theobroma cacao }\end{array}$ & UFLA \\
3 & CP02 & C & Itabuna BA & UES \\
4 & FA 42 & C & Barro Preto BA & Theobroma cacao & AC \\
5 & FA 277 & C & Barro Preto BA & Theobroma cacao & AC \\
6 & FA 562 & C & Uruçuca BA & Theobroma cacao & AC \\
7 & FA 563 & C & Barro Preto BA & Theobroma cacao & AC \\
8 & DOA-106 & S & Juiz de Fora MG & Solanum lycocarpum & CEPLAC \\
9 & RWB-551 & S & Juiz de Fora MG & Solanum lycocarpum & UFV \\
\hline
\end{tabular}

*UW (University of Wales), in Aberystwyth, U.K.; UFLA (Universidade Federal de Lavras) in Lavras, Minas Gerais, Brazil; UESC (Universidade Estadual de Santa Cruz) in Ilhéus, Bahia, Brazil; AC (Almirante Cacau) in Itajuípe, Bahia, Brazil; CEPLAC (Comissão Executiva do Plano da Lavoura do Cacau) in Ilhéus, Bahia, Brazil; UFV (Universidade Federal de Viçosa) in Viçosa, Minas Gerais, Brazil. 
by Specht et al. (1982). PCR-amplification was performed with the following program: 40 cycles of $1 \mathrm{~min}$ at $94^{\circ} \mathrm{C}, 1$ min at $55^{\circ} \mathrm{C}, 1 \mathrm{~min}$ at $72^{\circ} \mathrm{C}$, and a final extension of $10 \mathrm{~min}$ at $72^{\circ} \mathrm{C}$. The reactions were prepared in a $25 \mu \mathrm{L}$ volume, containing $1 \mathrm{x}$ thermophilic DNA poly Buffer (Promega), 2.5 $\mathrm{mM} \mathrm{MgCl}_{2}$ (Promega), $100 \mu \mathrm{M}$ each of dNTP, $0.5 \mu \mathrm{M}$ of each primer, $20 \mathrm{ng}$ of DNA and one unit of Taq DNA polymerase (Promega). Negative controls (no DNA template) were used for each set of experiments to test the occurrence of nonspecific amplification. DNA products were analyzed by electrophoresis in a $1.5 \%(\mathrm{w} / \mathrm{v})$ agarose gel or precipitated for restriction analysis with the restriction enzymes $A v a \mathrm{I}$ and $E c o$ RI. The DNA fragments originated from the cleavage reactions were analyzed in $2 \%(\mathrm{w} / \mathrm{v})$ agarose gel.

\section{Cloning, sequencing, and sequence analyses}

Amplified fragments using total DNA from $\mathrm{CP} 02$, SABA, and DOA-106 isolates were cloned into the TOPO vector (Invitrogen Life Technologies) or the pGEM TEasy vector (Promega), according to the manufacturer's instructions. Sequencing of DNA was carried out by using BigDye $^{\circledR}$ Terminator v.3.1 Cycle Sequencing Kit (Applied Biosystems) in a MegaBase 1000 DNA Analysis System (Molecular Dynamics \& Life Science). Resulting DNA sequences were used to search the data banks using the BLAST Service Network at NCBI (www.ncbi.nlm.nih.gov/ BLAST). Subsequent DNA and deduced protein sequence analyses were carried out using the CLUSTAL W program for multiple alignments (Thompson et al., 1994).

\section{Southern blot analysis}

Size fractionation of total DNA $(3.0 \mu \mathrm{g})$ digested with the restriction enzyme BamHI (chosen for not cutting the RT sequence) was performed in a $0.7 \%$ agarose gel and transferred onto a Duralon-UV ${ }^{\mathrm{TM}}$ membrane (Stratagene), according to standard protocols (Sambrook et al., 1989). Hybridization was carried out at $65^{\circ} \mathrm{C}$, using as probe a 394 bp DNA fragment with similarity to an RT from isolate CP02. Labelling, hybridization and detection were performed using the "Gene Images ${ }^{\mathrm{TM}}$ Random Primer Labelling Module and CDP-Star ${ }^{\mathrm{TM}}$ Detection Module" (Amersham), according to the manufacturer's protocols.

\section{RESULTS}

Using RT1 and RT2 oligonucleotides, a fragment of expected size (394 bp) was amplified from total DNA of the isolates tested (Figure 1), thus indicating the ubiquity of a putative element carrying the RT sequence in the genome of C. perniciosa.

To demonstrate that such oligonucleotides amplify RT sequences belonging to different copies of a putative transposable element, PCR products from the different isolates were cleaved with restriction enzymes and originated polymorphic fragments (Figure 2). These different restriction patterns are related to the presence of several copies of the

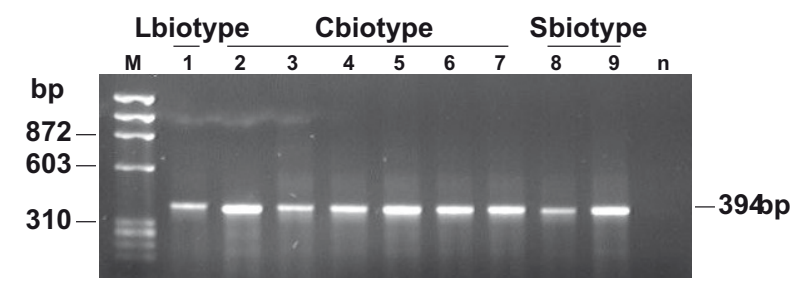

FIG. 1 - PCR products (394 bp) from C. perniciosa obtained with primers RT1 and RT2 as described in this work. Numbers 1 to 9 indicate $C$. perniciosa isolates listed in Table 1. Molecular marker in bp is indicated by M ( $\phi \mathrm{X} 174$ DNA digested with HaeIII). N indicates negative control of PCR amplification (mixture reaction without DNA template).

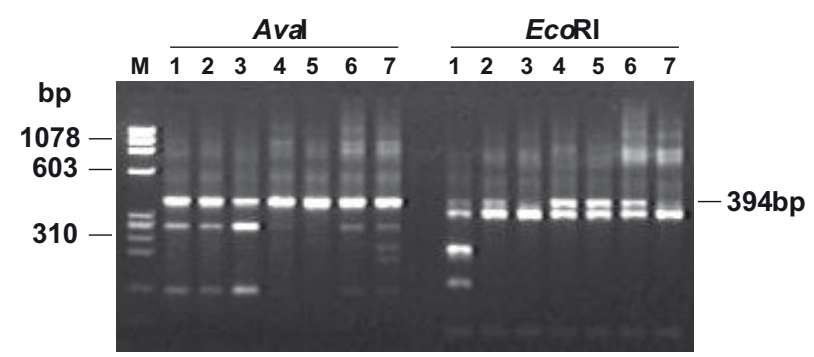

FIG. 2 - Restriction fragments of the PCR-amplified RT sequences from $C$. perniciosa obtained by digestion with AvaI and EcoRI. Numbers 1 to 7 indicate C. perniciosa isolates listed in Table 1. Molecular marker in bp is indicated by M ( $\phi$ X 174 DNA digested with HaeIII).

same element undergoing different modifications. This result was confirmed by the sequencing of the PCR products obtained from isolate CP02 (the same isolate used in witches' broom genome project). Nine cloned fragments were sequenced and compared with the original database sequence (Figure 3). All 10 sequences showed a few differences, sharing $95.4 \%$ of total sequence identity. Data also revealed that the differences between the amplified fragments are short, generally singlepoint mutations. In addition to small insertions and deletions, 51 mutations were characterized as base substitution, with 10 transvertions and 41 transitions (Figure 3).

Southern analyses were conducted to verify the copy number and distribution of RT-like sequences within $C$. perniciosa isolates (Figure 4). The high number of visualized signals suggests that the RT homologous sequences are present in large copy number. Since the signals with higher intensity of hybridization possibly represent elements with more than one copy on the same fragment, it is difficult to determine the exact number of sequences in each isolate. However, distinct profiles were observed for the different biotypes. At least one $4.10 \mathrm{~kb}$ fragment was found present in all the isolates analyzed, whereas $5.10,4.80$, and $2.30 \mathrm{~kb}$ fragments were found only in the C-biotype isolate. Among Cbiotype isolates analyzed, a $1.60 \mathrm{~kb}$ polymorphic fragment was present in isolates 3,5 , and 7 , but appeared absent in the others, 


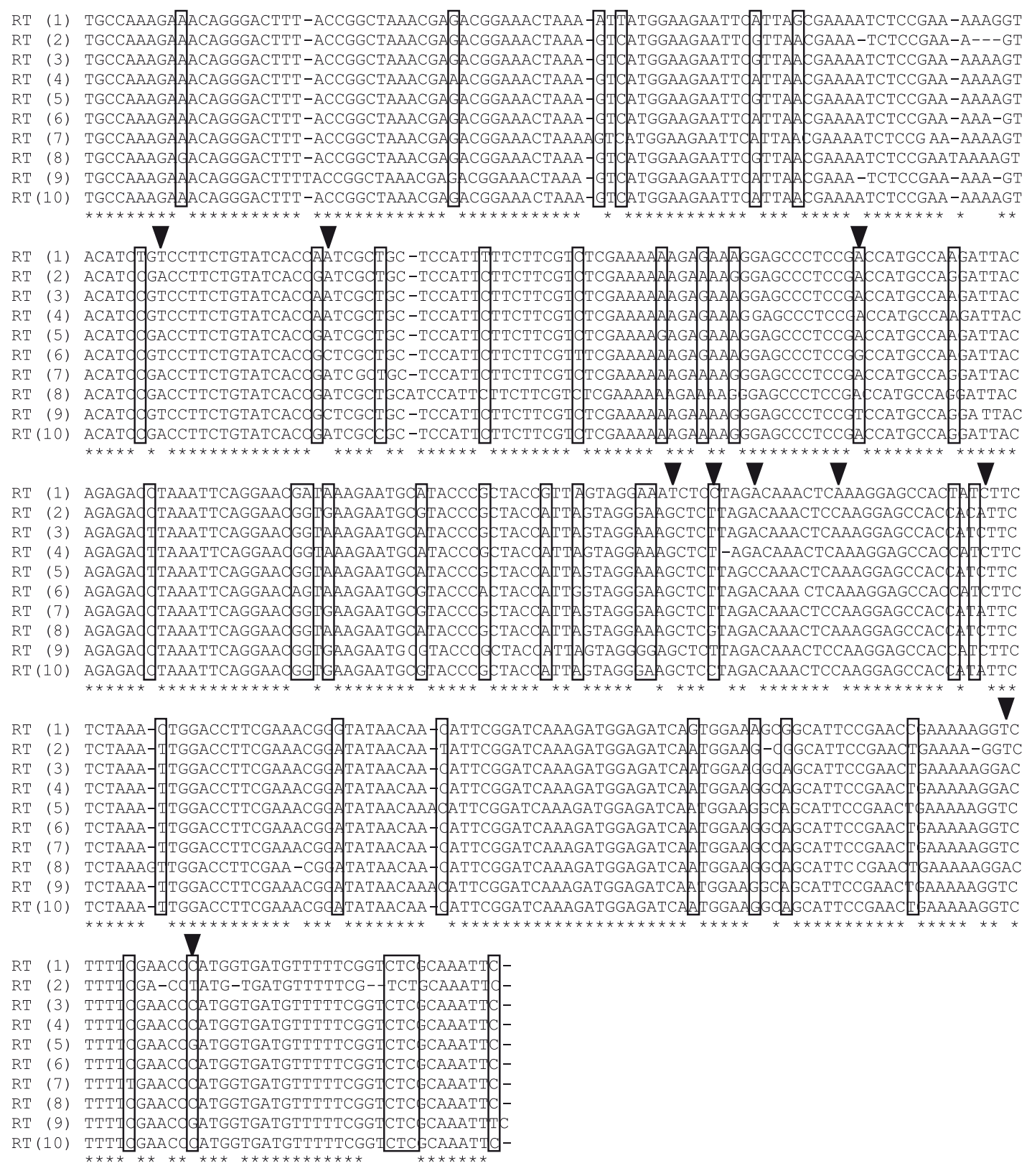

FIG. 3 - Alignment of the RT-like sequences. RT (1) indicates the sequence obtained from the sequencing database project (GenBank n ${ }^{\circ}$ AY676620); RT (2 to 10) indicates the sequences of fragments obtained in this work (GenBank numbers AY676609, AY676610, AY676611, AY676612, AY676613, AY676614, AY676615, AY676617, AY676618). * indicates presence of the same base in all the sequences; - indicates the presence of gaps. Boxes indicate transitions, and black triangles indicate transvertions.

indicating the presence of at least two hybridization profiles.

The deduced partial amino acid sequence of the putative RT protein was aligned with the homologous proteins from other filamentous fungi (Figure 5). The $C$. perniciosa deduced RT protein showed significant amino acid sequence identity with the RT domains of a number of fungal retrotransposon sequences of the gypsy family. The CpC1 RT peptide (RT sequence from isolate 2, GenBank no. AY676620) showed the highest degree of sequence identity
(64.6\%) with the PcGR1 RT domain (GenBank AY425728) described in the homobasidiomycete Phanerochaete chrysosporium Burds. Other retroelements that share identity with the C. perniciosa RT partial protein sequence are $\operatorname{marY1}$ (GenBank BAA78625) from Tricholoma matsutake (S. Ito \& S. Imai) Singer (57.6\%), cgRET (Genbank AAG24792) from Colletotrichum gloeosporioides (Penz.) Sacc. (53\%), an RT sequence (GenBank BAA92704) from Tricholoma bakamatsutake Hongo (52.3\%), MAGGY (GenBank 


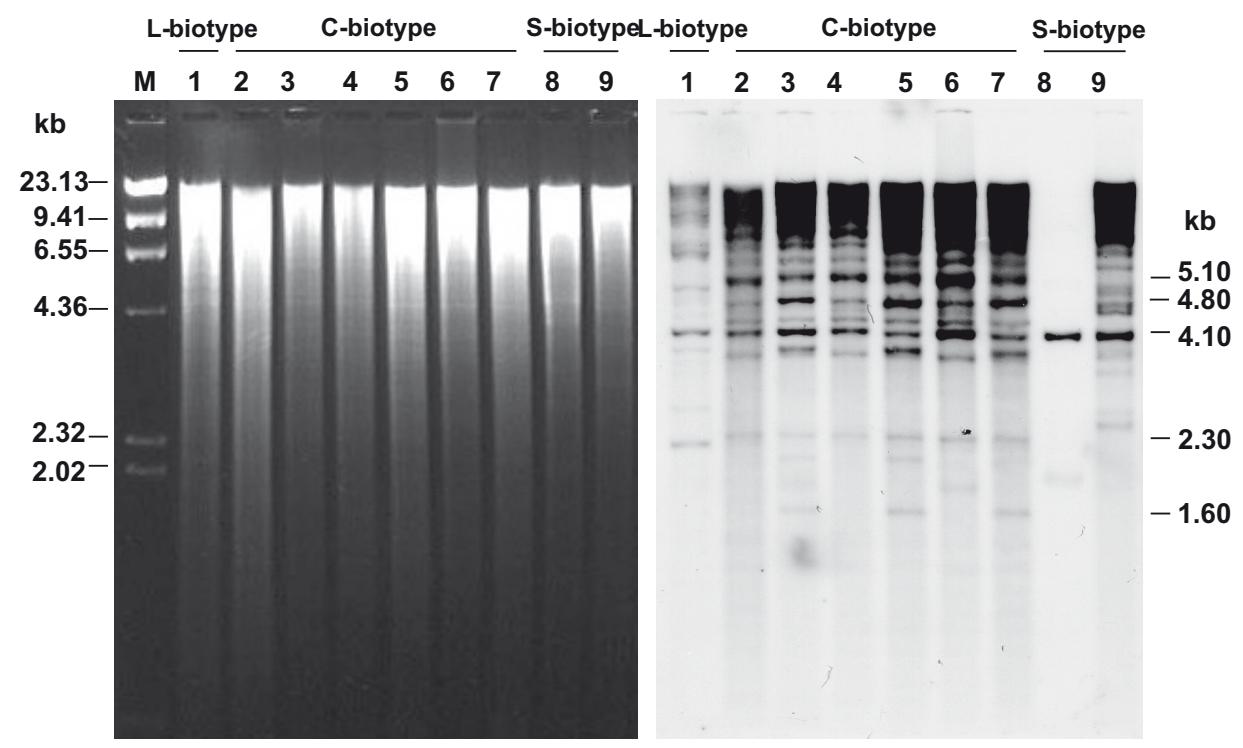

FIG. 4 - Southern blot analysis of total DNA from C. perniciosa isolates using the RT amplified sequence as probe. Numbers 1 to 7 indicate $C$. perniciosa isolates listed in Table 1 . Total DNA was cut with BamHI and fractionated in $0.7 \%$ agarose gel. Molecular size marker $\lambda$ HindIII is indicated in $\mathrm{kb}$ on the left. Fragments showed in the right are discussed in the text.

L35053) from M. grisea (45.3\%), and Foret (GenBank X65452) from Fusarium oxysporum Schlecht. (36.9\%). All of these retroelements belong to the Ty3/gypsy group of retrotransposons, indicating that this $C$. perniciosa RT sequence has been amplified possibly from a gypsy-like LTR retrotransposon. The amino acid sequences from $C$. perniciosa C-, S-, and L-biotypes share 95\% of identity, and the $\mathrm{CpC} 1$ and $\mathrm{CpC} 2 \mathrm{RT}$ sequences, belonging to two different C-biotype isolates (isolates 2 and 3 - see Table1), share $94.6 \%$ of identity. The CpC1 RT domain shares 93\% of identity with the S-biotype RT domain and $85.3 \%$ with the L-biotype RT domain.

\section{DISCUSSION}

The amplification, distribution, and analyses of putative genes encoding for reverse transcriptase in the witches' broom pathogen, Crinipellis perniciosa, are reported in this paper. RT-like sequences were amplified in all tested isolates belonging to different biotypes and geographical areas (Figure 1), which suggest that this sequence is probably an old genome resident of C. perniciosa. According to our current hypothesis, the putative element carrying the RT sequence from $C$. perniciosa would have been acquired from a common ancestor of the different biotypes and then inherited vertically by their descendants.

As an old resident of the C. perniciosa genome, the putative element carrying this RT sequence may have undergone modifications through time, thus originating different elements. To check for the presence of such different elements, a PCR-amplified product was cleaved and sequenced (Figures 1 and 2), originating different restriction fragments and different sequences, sharing $95.4 \%$ identity. The presence of differences in amino acid sequences is a common criterion used to group transposable elements into different families and subfamilies (Capy et al., 1998). For instance, the impala element of $F$. oxysporum shows approximately $1 \%$ differences within each subfamily, but between different subfamilies this difference may exceed 20\% (Hua-Van et al., 2001). In this context, RT copies amplified from $C$. perniciosa isolates may be related to elements of the same subfamily. The accumulation of alterations may generate transposable elements with defective structures (Daboussi, 1997) that could only be transposed by the reverse transcriptase in trans action of an autonomous element. Besides, the transition events $\mathrm{G}: \mathrm{C}$ to $\mathrm{A}: \mathrm{T}$ revealed in the different sequences could have resulted from RIP-like (repeated-induced point mutation) processes. Therefore, as revealed by Southern analyses, there are a high number of RT-like copies in $C$. perniciosa genome (Figure 3). Since RIP is a homologybased process that mutates repetitive DNA, the high copy number of retroelements found in C. perniciosa would lead to mutations in these repetitive sequences through a RIP-like process, which would control the activity of 
HH H K

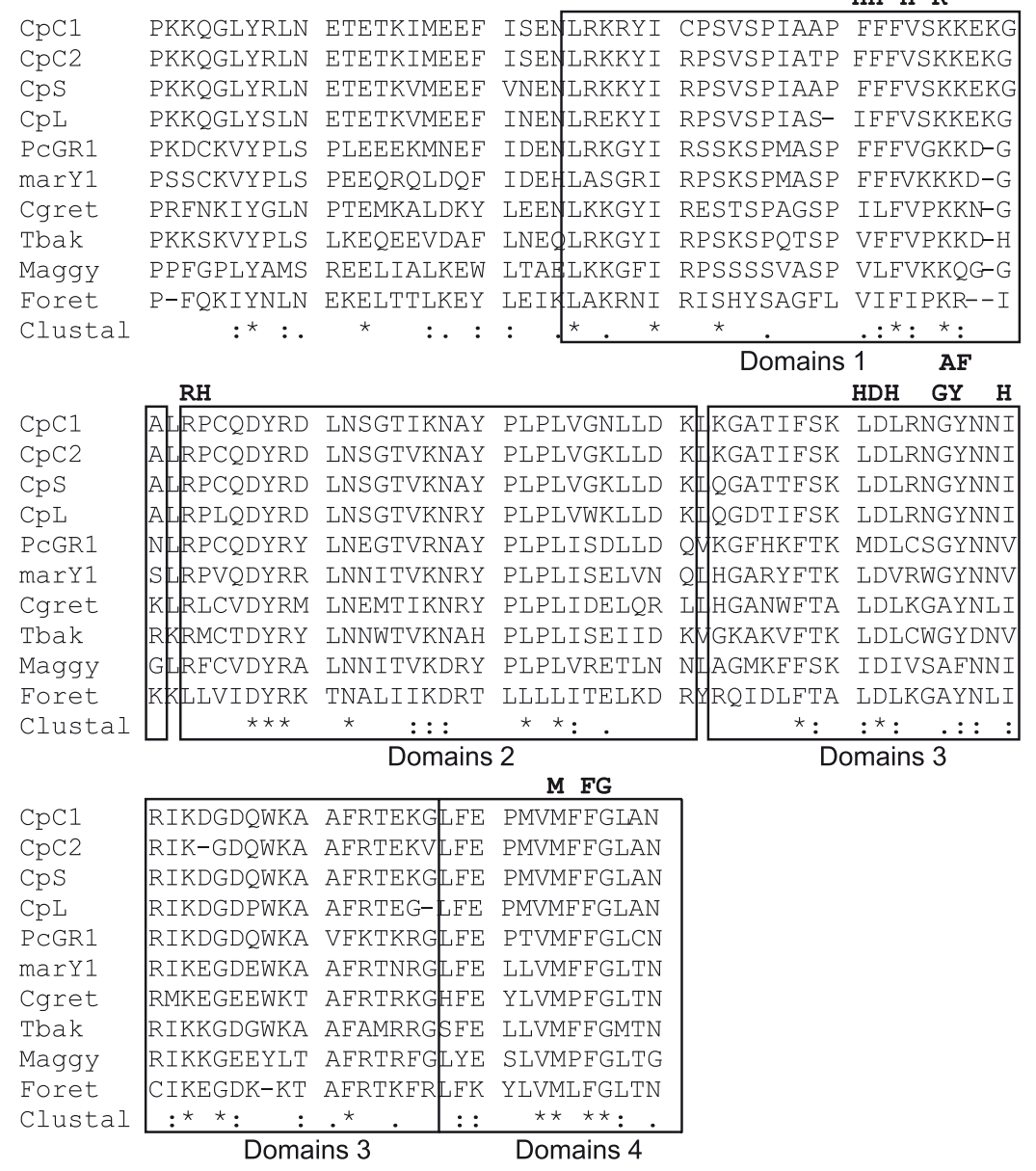

FIG. 5 - Deduced partial amino acid sequence from C. perniciosa RT protein aligned with the homologous polypeptides from different filamentous fungi. $\mathrm{CpC} 1$ (GenBank $\left.{ }^{\circ} \mathrm{AY} 676620\right)$ and $\mathrm{CpC} 2$ (GenBank ${ }^{\circ}$ AY676616) indicate RT from two different C. perniciosa C-biotype (isolates 2 and 3 - Table1); CpS (GenBank n ${ }^{\circ}$ AY676619) indicates RT from C. perniciosa S-biotype (isolate 8 - Table 1); CpL (GenBank n ${ }^{\circ}$ AY842857) indicates RT from C. perniciosa L-biotype (isolate 1 - Table 1). Other RT sequences: PcGR1 (GenBank AY425728), marY1 (GenBank BAA78625), CgRET (Genbank AAG24792), Tbak (GenBank BAA92704), MAGGY (GenBank L35053) and Foret (GenBank X65452). Boxes indicate RT domains (1 to 4) identified by Xiong and Eickbush (1990). Some unvaried or chemically similar residues are showed at the top (h, hydrophobic residue; p, small polar residue) as described in Xiong and Eickbush (1990). Hyphens show gaps and asterisks indicate conserved residue.

these retroelements.

The Southern analyses also revealed signal patterns indicating the presence of monomorphic and polymorphic fragments among isolates. The presence of monomorphic fragments corroborates with the hypothesis of a common origin for the $C$. perniciosa RT sequence, and the polymorphic fragments could be related to new insertion events, thus proving the activity of these retroelements.

Moreover, the presence of several copies of retroelements can generate mutations due to the insertion event, but may also serve as substrate for ectopic recombination events between the copies dispersed in the genome, both intra and interchromosomally. Such a recombination event may in turn cause retrotransposon losses (Mieczkowski et al., 2006). This type of mechanism could explain the different profile observed for isolate 8 (Figure 3).

Among the C-biotype isolates analyzed, a 1.60 $\mathrm{kb}$ polymorphic fragment was found present in isolates 3,5 , and 7 , but absent in the others, thus indicating the presence of at least two different hybridization profiles. In Bahia, the presence of two $C$. perniciosa genotypes was also detected by RAPD (Andebrhan et al., 1999) and two different chromosomal patterns were observed by electrophoretic karyotype analysis (Rincones et al., 2003; 2006). According to Andebrhan et al. (1999), the geographic distribution of the genetic groups in Bahia and the fact that $C$. perniciosa C-biotype is homothallic suggest the existence of two independent points of introduction of this pathogen into the cocoa-growing region of Bahia. Thus, 
the two different RT fingerprint profiles reported here by Southern analysis could also be correlated to the presence of two different genotypes in Bahia, Brazil. Therefore, the RT sequence is another important marker of genetic variability for this fungus.

Furthermore, evidence indicating that transposable elements may play a central role in restructuring evolutionary genomes has been accumulated in a growing number of organisms. In phytopathogenic fungi, the role of these elements has been reported for the genome reorganization of $F$. oxysporum (Davière et al., 2000) and in generating DNA fingerprint variation in $M$. grisea (Shull \& Hamer, 1996a,b). In F. oxysporum, the high level of chromosomal polymorphism was correlated to the concentration of transposable elements resulting from ectopic recombination between dispersed copies (Davière et al., 2001). Thus, the widespread presence of RT elements in the genome of $C$. perniciosa may also account for the genetic variability observed in this phytopathogen.

Alignment of the Cp-RT deduced protein with homologous sequences from Genbank revealed that the putative element carrying this sequence belongs to the gypsy family of retroelements. The Ty3/gypsy family is the most successful group of the retroelements dispersed in the genome of filamentous fungi, since they represent the majority of the 30 retroelements described so far (Daboussi \& Capy, 2003). The similarity of the RT protein is higher between the two isolates from C-biotype analyzed (94.6\%), and the L-biotype RT protein is more divergent (85.3\%) than the S-biotype RT protein (93.0\%), when compared with the sequence from C-biotype.

In conclusion, the ubiquity of the RT sequence in C. perniciosa biotypes suggests an ancestral origin and vertical inheritance of this sequence by the host progenies. The transposition of the retroelements carrying this sequence generated a high copy number and polymorphic fragments in the different biotypes. Moreover, this activity seems to occur in spite of the presence of several transitions in different RT sequences supporting the existence of a control process. The RT protein analysis indicates that this sequence possibly belongs to a gypsylike retroelement with high similarity with RT from other phytopathogenic fungus. Although the mechanisms for generation of genetic diversity remain to be defined, we showed that sequences related to transposable elements may be important to the genetic variability and evolution in C. perniciosa, the most important pathogen of cocoa in Brazil.

\section{ACKNOWLEDGMENTS}

The authors gratefully acknowledge financial support given by the agencies Conselho Nacional de Desenvolvimento Científico e Tecnológico - CNPq, Coordenação de Aperfeiçoamento de Pessoal de Nível Superior - CAPES, Fundação de Amparo à Pesquisa do Estado de São Paulo - FAPESP, and Secretaria de Agricultura do Estado da Bahia - SEAGRI.

\section{REFERENCES}

ANDEBRHAN, T., FIGUEIRA, A., YAMADA, M.M., CASCARDO, J. \& FURTEK, D.B. Molecular fingerprinting suggests two primary outbreaks of witches' broom disease (Crinipellis perniciosa) of Theobroma cacao in Bahia, Brazil. European Journal of Plant Pathology 105:167-175. 1999.

ATTARD, A., GOUT, L., ROSS, S., PARLANGE, F., CATTOLICO, L., BALESDENT, M.H. \& ROUXEL, T. Truncated and RIPdegenerated copies of the LTR retrotransposon Pholy are clustered in a pericentromeric region of the Leptosphaeria maculans genome. Fungal Genetics and Biology 42:30-41. 2005.

ARRUDA, M.C.C., FERREIRA, M.A.S.V., MILLER, R.N.G., RESENDE, M.L.V. \& FELIPE, M.S.S. Nuclear and mitochondrial rDNA variability in Criniepllis perniciosa from different geographic origins and hosts. Mycological Research 107:25-37. 2003.

BASTOS, C.N. \& EVANS, H.C. A new biotype of Crinipellis perniciosa (Witche's broom disease) on solanaceous hosts. Plant Pathology 34:202-205. 1985.

BASTOS, C.N., ANDEBRHAN, T. \& ALMEIDA, L.C. Comparação morfológica de isolados de Crinipellis perniciosa. Fitopatologia Brasileira 13:202-205. 1988.

BOUVET, G.F., JACOBI, V. \& BERNIER, L. Characterization of three DNA transposons in the Dutch elm disease fungi and evidence of repeat-induced point (RIP) mutations. Fungal Genetics and Biology 44:430-443. 2007.

CAMBARERI, E.B., JENSEN, B.C., SCHABTACH, E. \& SELKER, E.U. Repeat-induced C-G to A-T mutations in Neurospora crassa. Science 244:1571-1575. 1989.

CAPY, P., LANGIN, T., HIGUET, D. \& BASIN, C. Do the integrases of LTR-retrotransposons and class II element transposases have a cammon ancestor? In: Capy, P. (Ed.) Evolution and Impact of Transposable Elements. Contemporary Issues in Genetics and Evolution. Vol. 6. Heidelberg. Springer Verlag. 1998. pp. 63-72.

DABOUSSI, M.J. Fungal transposable elements and genome evolution. Genetica 100:253-260. 1997.

DABOUSSI, M.J. \& CAPY, P. Transposable elements in filamentous fungi. Annual Review of Microbiology 57:275-299. 2003.

DAVIÈRE, J.M., LANGIN, T. \& DABOUSSI, M.J. Potential role of transposable elements in the rapid reorganization of the Fusarium oxysporum genome. Fungal Genetics and Biology 34:177-192. 2001

EVANS, H.C. Witches' broom disease of cocoa (Crinipellis perniciosa) in Ecuador. Annals of Applied of Biology 89:185-192. 1978.

GALAGAN, J.E. \& SELKER, E.U. RIP: the evolutionary cost of genome defense. Trends in Genetics 20:417-423. 2004.

HAMANN, A., FELLER, F. \& OSIEWACZ, H.D. The degenerate DNA transposon Pat and repeat-induced point mutation (RIP) in Podospora anserina. Molecular and General Genetics 263:10611069. 2000. 
HEDGER, J.N., PICKERING, V. \& ARAGUNDI, J.A. Variability of populations of the witche's broom disease of cocoa (Crinipellis perniciosa). Transaction of British Mycological Society 88:533546. 1987.

HOOD, M.E., KATAWCZIK, M. \& GIRAUD, T. Repeat-induced point mutation and the population structure of transposable elements in Microbotryum violaceum. Genetics 170:1081-1089. 2005.

HUA-VAN, A., PAMPHILE, J.A., LANGIN, T. \& DABOUSSI, M.J. Transposition of autonomous and engineered impala transposons in Fusarium oxysporum and a related species. Current Genetics 264:724-731. 2001.

KAZAZIAN JR, H.H. Mobile elements: drivers of genome evolution. Science 303:1626-1632. 2004.

KINSEY, J.A. \& HELBER, J. Isolation of a transposable element from Neurospora crassa. Proceedings of the National Academy of Sciences of the USA 86:1929-1933. 1989.

KINSEY, J.A., GARRET-ENGELE, P.W., CAMBARERI, E.B. \& SELKER, E.U. The Neurospora transposon Tad is sensitive to repeat-induced point mutation (RIP). Genetics 138:657-664. 1994.

MIECZKOWSKI, P.A., LEMOINE, F.J. \& PETES, T.D. Recombination between retrotransposons as a source of chromosome rearrangements in the yeast Saccharomyces cerevisiae. DNA Repair 5:1010-1020. 2006.

NAKAYASHIKI, H., NISHIMOTO, N., IKEDA, K., TOSA, Y. \& MAYANA, S. Degenerate MAGGY elements in a subgroup of Pyricularia grisea: a possible example of successful capture of a genetic invader by a fungal genome. Molecular General of Genetics 261:958-966. 1999.

NEUVÉGLISE, C., SARFATI, J., LATGE, J.P. \& PARIS, S. Afut1, a retrotransposon-like element from Aspergillus fumigatus. Nucleic Acids Research 24:1428-1434. 1996.

PURDY, L.H. \& SCHMIDT, R.A. Status of cacao witches' broom: biology, epidemiology and management. Annual Review of Phytopathology 34:573-594. 1996.

RINCONES, J., MEINHARDT, L.W., VIDAL, B.C. \& PEREIRA, G.A.G. Electrophoretic karyotype analysis of Crinipellis perniciosa, the causal agent of witches' broom disease of Theobroma cacao.
Mycological Research 107:452-458. 2003.

RINCONES, J., MAZOTTI, G.D., GRIFFITH, G.W., POMELA, A., FIGUEIRA, A., LEAL, G.A., QUEIROZ, M.V., PEREIRA, J.F., AZEVEDO, R.A., PEREIRA, G.A.G., MEINHARDT, L.W. Genetic variability and chromosome-length polymorphisms of the witches' broom pathogen Crinipellis perniciosa from various plant hosts in South America. Mycological Research 110:821-832. 2006.

SAMBROOK, J., FRITSCH, E.F. \& MANIATIS, T. Molecular cloning: a laboratory manual, $2^{\text {nd }}$ Ed. New York. Cold Spring Harbor Laboratory Press. 1989.

SANGER, F., NICKLEN, S. \& COULSON, A.R. DNA sequencing with chain-terminating inhibitors. Proceedings of the National Academic of Science of the USA 74:5463-5467. 1977.

SELKER, E.U. \& GARRET, P.W. DNA sequence duplications trigger gene inactivation in Neurospora crassa. Procceedings of the National Academic of Science of the USA 85:6870-6874. 1988.

SELKER, E.U., CAMBARERI, E.B., JENSEN, B.C. \& HAACK, K.R. Rearrangement of duplicated DNA in specialized cells of Neurospora. Cell 51:741-752. 1987.

SHULL, V. \& HAMER, J.E. Rearrangements at a DNA-fingerprint locus in the rice blast fungus. Current Genetics 30:263-271. 1996a.

SHULL, V. \& HAMER, J.E. Genetic differentiation in the rice blast fungus revealed by the distribution of the Fosbury retrotransposon. Fungal Genetics and Biology 20:59-69. 1996b.

SPECHT, C.A., DIRUSSO, C.C., NOVOTNY, C.P. \& ULLRICH, R.C. A method for extracting high-molecular-weight deoxyribonucleic acid from fungi. Analytical Biochemistry 119:158-163. 1982.

THOMPSON, J.D., HIGGINS, D.G. \& GIBSON, T.J. CLUSTAL $W$ Improving the sensibility of progressive multiple sequence alignment through sequence weighting, position specific gap penalties and weight matrix choice. Nucleic Acids Research 22:4673-4680. 1994.

XIONG, Y. \& EICKBUSH, T.H. Origin and evolution of retroelements based upon their reverse transcriptase sequences. EMBO Journal 9:3353-3362. 1990. 